\title{
Mystified Alienation: A Discussion between Marx, Foucault and Federici
}

\author{
Christian Fajardo
}

Pontificia Universidad Javeriana, Bogotá, Colombia, cjulian.fajardoc@javeriana.edu.co

\begin{abstract}
This article explores Karl Marx's critique of alienation. Specifically, I will argue that the concept of alienation is essential to understand not only how capitalism reproduces itself, but also to find alternatives to a regime of capital valorisation that has become mystified. In order to develop the analytical scope of this critique, I propose to discuss it together with the Foucauldian concept of disciplinary power and with the concept of patriarchal violence that appears in Silvia Federici's Caliban and the Witch. These two approaches provide a basis for the statement that the Marxist critique of alienation can be complemented and radicalised with the post-structuralist position, and with the feminist critique of capitalism.
\end{abstract}

Keywords: alienation, capitalism, disciplinary power, patriarchal violence, Karl Marx, Michel Foucault, Silvia Federici

\section{Introduction}

It may be said that one of the central concepts in Marx's thought is alienation (Entfremdung). However, to approach it carefully, it is necessary to specify that his reflection has some displacements that must be taken into account. For example, in Capital $(2017 ; 2004 a)$ there is a specific notion of alienation, which the same author had been developing in the Grundrisse (2007). Notebook VII of the Grundrisse articulates that capitalism can only exist when capital appropriates alienated labour. However, the acuteness of Marx's analysis consists in the fact that this appropriation only occurs as long as alienation appears itself as a historical necessity (Marx 1973, 831). To this historical dimension of alienation, David Harvey (2018) has given the name of universal alienation. For their part, Negri and Hardt (2018) prefer to make use of the concepts of real and formal subsumption that Marx develops in Capital. Common between these two positions is the idea that capitalist relations of production are conditioned by a generalisation of valorisation processes towards spheres that were not historically the concern of markets. For that reason, while Negri and Hardt argue that what needs to be observed is not so much the subsumption of labour under capital but of society under capital (2018, 442), Harvey notices that alienation is not confined to labour $(2018,426)$. However, there is a third aspect that I propose to discuss: the mystified form of alienation. Accordingly, I would like to argue that alienation captures social relations when, in our ideological life, the valorisation of capital becomes a necessary and, presumably, incontrovertible historical process. To do so, capitalist relations must deny politics and present it as an erratic and meaningless human practice. In the epilogue to the second edition of the first volume of Capital, Marx points out that dialectics in its mystified form seeks to "glorify the existing state of things" (2004a, 20). In this article I will seek to show that alienation intends to glorify the existing state of things by making it appear to be a necessary process. 
Through this specific concept of the mystified form of alienation, it is thus possible to claim that the domination of capital over human life is not the direct imposition of one class on another, but the formation of historical conditions that force human beings to make certain decisions and not others. Taking this into account, for Marx the capitalist has a double objective that $\mathrm{s} / \mathrm{h}$ cannot evade. S/he must manage, on the one hand, the social work process for the elaboration of a product and, on the other, the process of valorisation of capital $(2017,406)$. In this way, the despotism of this social order does not consist in the will of the capitalist, but in the conditions that impel him/her to make a certain decision. For this reason, the capitalist, despite being placed in a privileged position, is the victim of mystified alienation. Conditions force him/her to make one decision and not another. On the worker's side, something similar happens, but with a greater degree of violence. The conditions appear to him/her as the authority of the capitalist or as "the powerful will of another (eines fremden Willens), who subjects their activity to his aims" (Marx 2004a, 337; 1987, 328). Capitalism is thus a mode of production of meaning and of the world in which our decisions are mediated by impersonal processes that, despite being equivocal and contingent, appear necessary. But how has the process of capital valorisation become a historical necessity? How can we understand that capitalism has captured not only economic relations but also our ways of symbolising reality?

To address the above questions, I argue that mystified alienation seeks to conjure up the conditions that prevent the valorisation of capital. These limit-conditions of capital are non-alienated forms of life and political practice. I will point out that a critical approach to this mystified form of alienation allows us not only to understand how capitalism has become a world system, as suggested by Harvey and by Negri and Hardt, but also to learn to see its limits. Accordingly, this article intends to show that despite the fact that conditions force some to dominate others, the study of this dimension of human relationships is essential in order to develop a concept of a non-alienated life, a life that resists and escapes from the logic of valorisation of capital. In the process of formal and real subsumption of labour under capital, there are certain activities that cannot be integrated into valorisation processes. This practice is that of politics in its resistant form. In this article I seek to conceptualise how mystified alienation seeks to exclude and deny this dimension of human life, because it cannot be included in capitalism. I will not point to concrete alternatives to capitalism, but to a way of reading capitalist relations at their very limits. I believe that this is the theoretical gesture that we can find in Capital and in contemporary political philosophy.

To develop this hypothesis, I have divided this article into three parts. Firstly, I focus on the Marxist concept of alienation that appears in Capital, and the ways in which Karl Marx's thought can be used to conceptualise a non-alienated form of life. Secondly, I explore how the Foucauldian concept of disciplinary power can be read as a form of mystified alienation. In fact, for Foucault, one of the primary functions of disciplinary power is to exclude and even confine to criminality all human action that does not allow for the valorisation of capital. For him, one of the central characteristics of disciplinary power is that of criminalising political action. Finally, I turn my attention to the perspective of Silvia Federici. I point out that her concept of patriarchal violence can be approached from the point of view of alienation, because the degradation suffered by women in the capitalist world contributes precisely to the denial of a way of life that escapes the processes of valorisation. 


\section{Marx: Two Forms of Alienation}

It is possible to argue that the concept of alienation appears in Marx's early work, specifically in The Economic and Philosophic Manuscripts (2013), in On the Jewish Question (2004b), and in Contribution to the Critique of Hegel's Philosophy of Law (1975). Following Feuerbach's legacy, the notion of alienation in the young Marx's work consists in the fact that capitalist production dispossesses human beings of their capacity to produce the world. Alienation in this case consists in reversing the order of predication: human beings are no longer the artificers of the things they produce, nor of their own juridical institutions. They become objects of their own creations. For this reason, in an alienated world, while the market and the State appear as unconditioned and necessary subjects, human beings appear as passive objects. Marx (2005, 272), in The Manuscripts, argues that "the devaluation of the human world is in direct proportion to the increasing value of the world of things". This approach to the notion of alienation poses two consequences. On the one hand, it is suggested that alienation dispossesses human beings of an instituting capacity that ontologically belongs to them; on the other, it is considered that emancipation will begin when human beings claim to be the true architects of the world.

However, the idea of alienation as an inversion of subject and predicate is abandoned by Marx. It is no longer a question of thinking of an idealised subject who must claim to be the true author of the things he produces, but rather of how the capitalist mode of production historically conditions our existence. Following this change in Marx's perspective, Harvey $(2018,426)$ points out that in the Grundrisse there is a genuine interest in situating human existence in the reality "of the daily life and labours of workers as constituted within a capitalist mode of production". In Harvey's view, this proposal is not a simple change in epistemological perspective, but a radical reformulation. Marx's concern is to show that alienation occurs within capital's need to create a global market. To that extent, alienation becomes a universal condition that permeates not only the existence of workers, but also that of consumers, sellers, capitalists, and society. Marx understands very well that the universality of the global market and the valorisation of capital is the universalisation of alienation. However, going beyond Harvey's point, I suggest that alienation in Marx's later works can be understood not only through its universal point of view, but also through its mystified character, because the valorisation of capital appears as an historical necessity that forces subjects to make certain choices. We can verify this suggestion in Capital (2004a), specifically in Chapter 8, which is devoted to the working day.

As I have pointed out, Marx abandons the critique of alienation from a normative concept of the human condition. Instead, he chooses to make an empirical analysis to verify how the valorisation of capital becomes a historical necessity. Taking this into account, Marx points out that "he [the capitalist], like all other buyers, seeks to get the greatest possible benefit out of the use value of his commodity" (2004a, 241-42). With this statement, Marx asserts that the capitalist cannot avoid exploiting to the maximum the labour power he hires, because the market 'forces' him to prolong the worker's productivity, i.e., the time he devotes to the production of surplus value. ${ }^{1}$ Although it is

\footnotetext{
${ }^{1}$ At the beginning of Section V of Capital, Marx warns that "capitalist production is not only the production of commodities, it is, in essence, the production of surplus value" $(2017,589)$. These words affirm the idea that capitalism assumes that labour can only become productive to the extent that it valorises capital, that is, when its activity succeeds in producing surplus value through surplus labour. I develop the relation between the commons and surplus value in Fajardo (2020).
} 
true that this relationship is a privilege of a dominant class that enjoys the benefits of the labour of others, Marx focuses his analysis on specifying its objective dimension or, in other words, the heteronomy that conditions the decisions made by human beings. With this in mind, the following statement from the Eighteenth Brumaire (Marx 1978,104 ) is relevant: "Men make their own history, but they do not make it just as they please; they do not make it under circumstances chosen by themselves, but under circumstances directly encountered, given and transmitted from the past". In short, the capitalist seeks to ensure the valorisation of capital not because he makes the decision freely and unconditionally, but because his past and history force him to make the greatest possible profit from the commodity he acquires. However, this does not mean that capitalists are not responsible for the process of valorisation of capital. Rather, the question is to show that "the persona of many capitalists is profoundly shaped by the practices they have to perform" (Harvey 2018, 426). In short, despite the fact that history alienates the capitalist, in this process s/he him/herself reproduces and performs the conditions that make him/her exist. It is thus a dialectical understanding of the relationship between conditions and human action. When the capitalist considers him/herself the owner of the labour power s/he buys, a story appears that tells him the following: 'in reality I have you, capitalist'. Nevertheless, how does this mystified alienation operate in the condition of the worker?

Marx is emphatic in showing that the universalisation of the world market manifests itself in the bodies of the workers in a specific way. If the capitalist is forced by the search for surplus value, trying to get the most out of the labour power that he buys, the worker is forced to work for the capitalist, but also to resist producing that surplus value. "Suddenly" - Marx writes - "the voice of the labourer, which had been stifled in the storm and stress of the process of production, rises" (2004a, 242). As Harvey points out, workers tend to protest against the valorisation of capital because there is something fraudulent in the sale of their labour power, even if it is legal $(2018,426)$. This fraud, in the argumentation of Capital, is that of surplus labour time, that is, labour time that remains unpaid because it is the basis of the valorisation of capital. In return, he or she receives merely means of subsistence. His or her life, capacities, intelligence, are appropriated by the necessity to set value in motion, a necessity that is, in any case, historical and contingent.

According to the above, the concept of alienation which reappears in 1858 and which is prolonged in the argumentation of Capital (2004a) has an objective and a subjective character. The first is that which forces the capitalist to make the maximum profit from the commodities s/he buys. Among these, labour power is the most important, since it is the only commodity that is capable of valorising capital. This objective character of alienation also appears in the lives of workers when circumstances force them to sell their labour power in the market. Nevertheless, alienation manifests itself in a subjective way. At this level, alienation becomes mystified because it appears as if necessary in the ideological life of human beings. While the capitalist considers himself/herself the owner and master of capital and the commodities that s/he acquires, the worker feels betrayed by the contract that s/he signs with the capitalist. $\mathrm{His} /$ her life is spent in frustration, but also in his/her ability to assert "his right as seller when he wishes to reduce the working day to one of definite normal duration" (Marx 2004a, 243). In short: alienation becomes mystified alienation, because it forces human beings to make decisions that guarantee the reproduction of capitalism, even though they are aware of the violence and arbitrary nature of capitalist exploitation (Žižek 2008, 28). However, this mystification has an obvious limit when the right of the capitalist as buyer, and the right of the worker as seller, clash. Their class position 
causes a clash of rights to take place, an antinomy in which only force decides the outcome, in Marx's view (2004a, 243). Accordingly, what would be Marx's lesson with that reformulated concept of alienation?

In my view, this reformulation seeks to problematise the idea that emancipated human beings are those who can control their relationship with things and history. ${ }^{2}$ In Marx's later works, the problem is not to make alienation disappear entirely and claim that human beings are the true architects of the world. Instead, Marx shows that alienation is a logic of sense in which certain violent practices, such as the valorisation of capital, appear necessary and inevitable. The danger of capitalist alienation thus consists in extending the historical necessity of capital valorisation into all spheres of human life, making other forms of life no longer relevant. To this logic of mystified sense, Jacques Rancière gives the name "police order" (1995). ${ }^{3}$ For him, the police order makes the existing state of things appear not as a lie or an inverted reality, as the young Marx suggests, but as a necessary process. Thus, a mystified social order is a distribution of the sensible that seeks to glorify the existing state of things. Accordingly, Marx points out that capitalism, despite being a transitory and contingent mode of production, appears definitive and necessary. In this lies the violence of mystified alienation. It is not a matter of an inversion between the subject and the predicate, but of showing that history follows a process that, presumably, we cannot stop. Marx's hope, his political stake, consists in showing that the existing state of things "includes, at the same time, the recognition of the negation of that state, of its inevitable breaking up; because it regards every historically developed social form as in fluid movement, and therefore takes into account its transient nature not less than its momentary existence" (2004a, 20). With this hope in mind, how is it then possible to understand a non-alienated and therefore non-mystified way of life?

As Jaeggi $(2014,32)$ points out, "the perspective from which the problem of alienation is approached ceases to be interesting when it presupposes a pre-established harmony among relations or seamless 'oneness' of individuals with themselves or with the world". Jaeggi's concern is thus to find a way of life that is not alienated, without falling into the myths of a human condition that is transparent with respect to itself. Here we encounter that Marx's approach proposes two tasks: on the one hand, to understand the historicity of an alienation that has become mystified; on the other and here lies his concept of the political - to find an alternative to alienation without falling into the idea of an individual who is the owner of himself and reconciled with his environment. Hence, a non-alienated life, that is, a life where human beings control their own destiny, is not what Marx's early work wanted to find. The alternative to an alienated life is, therefore, not one of possessive individualism, but one of experimentation, that is to say, a life that has as its horizon "an openness to revision and experimentation" (Jaeggi 2014, 40). This is also Merleau-Ponty's reading of Marx's thought in Humanisme et terreur (2010), for it is a matter of assuming that the human condition is that of the curse of life in plurality (maléfice de la vie à plusieurs):

${ }^{2}$ A very relevant tendency of post-Marxism has developed the idea that emancipation in Marx's thought consists in a reappropriation of a lost capacity. Miguel Abensour considers that Marx in his critique of Hegel's philosophy of right seeks to differentiate between alienated forms of life and non-alienated forms of life. The first is that of the religious life that the human being leads in the liberal state; the second is the democratic process in which there is an adequacy between the people and their objectifications in such a way that "the risk of precipitation of the objectification in alienation disappears" (Abensour 1998, 104).

${ }^{3}$ In the same direction, Arendt in The Human Condition (2018) develops the argument of how the alienation of the world seeks to depoliticise human affairs. 
The human condition may be such that it has no happy solution. Does not every action involve us in a game which we cannot entirely control? Is there not a sort of curse in collective life (maléfice de la vie à plusieurs)? (Merleau-Ponty 2010, 201).

Merleau-Ponty, like Jaeggi, suggests that the alternative to alienation is to assume a way of life that welcomes conflict and the opacity of human relations. It would then be necessary to fight against alienation, keeping in mind that human freedom is that of experimentation, or that of the curse of life in the plural. It is a matter of assuming that, in human affairs, there is no good solution, that conflict and some form of violence will always accompany social relations. However, is it possible to understand alienation beyond the relation between the worker and the capitalist? Is it possible to actualise Marx's critique of alienation?

This concept of mystified alienation allows Marx to situate the development of capitalism in the 19th century, with special emphasis on the relationship between the capitalist and the worker. However, contemporary political philosophy has sought, in various ways, to understand this type of subjection beyond this relationship. Michel Foucault and Silvia Federici remind us that the capitalist mode of production permeates practices that go beyond the antagonism between capital and labour. For this reason, in the two sections that follow, I would like to develop the Foucauldian concept of disciplinary power and Federici's notion of patriarchal violence as two ways of describing mystified alienation. I will read Foucault and Federici with Marx, noting that a study of the conditions of possibility of capitalism allows us to understand that mystified alienation has an unbreakable limit: political practice or non-alienated forms of life. ${ }^{4}$

\section{Foucault: Discipline as Alienating Power}

In contemporary political theory, the role of disciplinary power has not been addressed with sufficient attention. For example, Byung-Chul Han in The Burnout Society (2012) considers that disciplinary power does not serve to understand our present. According to Han, the Foucauldian concept of disciplinary power is too rigid because it is structured under the scheme of prohibition. This negative approach prevents an understanding of contemporary service-oriented societies whose principle is not the prohibition but the multiplication of human activity without the need for continuous vigilance (Han 2012, 25-28). However, this author's desire to consider that we are in an unprecedented epoch of the development of capitalism neglects the critical power of the Foucauldian notion of discipline. And this neglect arises through reducing the concept of disciplinary power to the institutions from which they emerge (prison, hospital, school, etc.). This desire for a transition to a new society, in Han's case a service-oriented one, does not take into account the core of the argumentation of a work like Discipline and Punish (Foucault 1995), which, in my view, can be approached as follows: the specificity of disciplinary power lies precisely in noting that this power distances itself from the juridical legalism of prohibition (formal domination of the State over bodies), in order to create a type of relations of domination, which has as its principle the need to make bodies more productive through their most categorical alienation. Moreover, this type of power cannot be understood without taking into account the class domination that runs through it from beginning to end. In the following, I will develop the concept

${ }^{4}$ In order to focus on the concepts of disciplinary power and patriarchal violence, I will pay special attention to Discipline and Punish (Foucault 1995) and Caliban and the Witch (Federici 2014). 
of disciplinary power without neglecting its profound closeness to the notion of mystified alienation discussed in the previous section. To do this, I will mobilise Foucault's approach to political crime and the process of accumulation of human beings.

For Foucault $(1995,223)$ it is not possible to understand disciplinary power without the class domination that founds it. In the 17th and 18th centuries, the reformers of punishment and criminal law sought to regenerate and change the behaviour of offenders. Accordingly, they considered that benign and proportional punishments resulted in a society with less crime and more civilised subjects. However, as Foucault makes clear, this claim was frustrated, especially in the 19th century, when workers' illegalities emerged and they began to organise their political struggle against "the new system of the legal exploitation of labour [...] from the most violent such as machine breaking, or the most lasting such as the formation of associations, to the most everyday, such as absenteeism, abandoning work, vagabondage, pilfering raw materials, deception as to the quantity and quality of the work completed" (Foucault 1995, 274). The disobedience of the workers in the 19th century led reformers to rethink their initial idea; it was no longer a matter of correcting the conduct of the offenders, but of making political struggle an expression of delinquency; in other words, no longer a matter of reducing crime, but of drawing a sense boundary between a series of behaviours adjusted to the demands of the relations of production and others that simply escaped the orbit of the valorisation of capital. In this case, it is possible to say that dominant classes reacted against popular illegalities to contain the bodies that resist the mystified alienation of capital, namely, the conditions that force both the capitalist and the worker to valorise capital. This perspective brings Foucault closer to Marx's critique of alienation.

It can be seen that Foucault $(1995,274-75)$ argues that disciplinary power becomes fundamental to contain not so much delinquency and political sabotage as the conditions that make them possible. With this in mind, the disciplinary power does not seek to repress bodies from the scheme of prohibition, but rather to train human behaviours in accordance with the valorisation of capital. Through this positive way of exercising power, disciplinary techniques conjure up all that resists mystified alienation. From this perspective, the significant contribution of Discipline and Punish $(1995,252)$ consists in showing that, for the disciplinary power, delinquency is not the conduct of the offender, but the latent possibility that every human being has of being unable to control his or her own destiny, or of living a life that resists the objective conditions that forces him or her to enter into the existential fraud of alienation. In other words: disciplinary power is an infra-law because it spreads, in our ideological life, the guilt of the MerleauPontian human condition: that of not being able to entirely control our relationship with history, with things and with others; that of not being able to find a definitive harmony in human affairs. As indicated in the previous section, this condition makes the valorisation of capital impossible, because it allows human beings to inhabit reality beyond alienation. Disciplinary power is thus a reaction to the experimentation and political resistance of the working class and, subsequently, of all human action that has sought a non-alienated way of life. This reaction can be understood with the following words of Foucault on disciplinary power, which appears in modern penitentiary techniques.

The delinquent is also to be distinguished from the offender in that he is not only the author of his acts (the author responsible in terms of certain criteria of free, conscious will), but is linked to his offence by a whole bundle of complex threads (instincts, drives, tendencies, character). The penitentiary technique bears not 
on the relation between author and crime, but on the criminal's affinity with his crime $(1995,252-53)$.

This quote suggests that penitentiary techniques, which emerge in the modern prison, set in motion a series of disciplinary powers that produce a disembodied reality. This is characterised by the fact that every infraction, which for criminal law is seen as the act of a perpetrator, is immersed in an impersonal historicity made up of tendencies, drives and instincts. Disciplinary techniques thus seek, on the one hand, to declare innocent any person who has a transparent relationship with himself or herself, with others, and with things; on the other hand, to declare as potential criminals anyone who fails to appropriate his or her own body by allowing the self to be dominated by his or her instincts, by his or her conditions and even by his or her belonging to a social class. This leads 19th-century criminal law theorists to say:

[...] that crime is not a potentiality that interests or passions have inscribed in the hearts of all men, but that it is almost exclusively committed by a certain social class; that criminals, who were once to be met with in every social class, now emerged 'almost all from the bottom rank of the social order' (Comte and Lauvergne, quoted in Foucault 1995, 275)

Disciplinary power, far from being a negative technique that represses bodies through rigorous surveillance measures, is constituted by a series of mechanisms that cause a sensible world to emerge. In this sensible world, a distinction emerges between bodies that dominate their own will, and bodies that yield their will to impersonal forces that potentially turn them into delinquents. It is interesting to note that this destiny exerts force on the bodies that belong to the dominated classes to a much greater extent. In other words: for disciplinary techniques, the most dangerous crimes are political crimes that usually emerge in the last ranks of the social order.

Following the criticisms appearing in some 19th-century Saint-Simonian newspapers such as L'Atelier and La Ruche Populaire, Foucault highlights how disciplinary power, in its struggle against bodies that resist the mystified alienation of capital, began to pay more attention to political crimes than to those of common law. "Verdicts" Foucault writes, citing those newspapers - "were often more severe against workers than against thieves. The two categories of convict were mixed in the prisons and preferential treatment given to common-law offenders" $(1995,286)$. This indicates that a significant element for understanding the violence produced by disciplinary power is the differentiation between two kinds of delinquents: the common and the political. The former falls into delinquency because s/he allows him/herself to be dominated by his/her instincts, desires, conditions, and so on. On the other hand, the latter falls into delinquency not only by allowing him/herself to be dominated simply by his/her conditioning, but also by the claim to transform and make impossible his/her assured destiny as a body that valorises capital. In other words, when reformers claim that political crime comes from the bottom rank of the social order, two things are being suggested: 1) that the popular classes - untrained bodies - are more prone to disobey the law; 2) that an obedient individual - be he or she a worker, unemployed, young person, student or consumer - is one who accepts the alienation of the relations of production. This acceptance is not a form of resignation, but a behavioural training, a disciplinary way of producing sense.

With this in mind, Foucault $(1995,209)$ points out that disciplinary power ceases to inhabit merely the institutions that gave birth to it, in order to generalise itself in society as a whole. In Foucault's opinion, this transition from the discipline-blockade typical of 
disciplinary institutions to discipline-mechanism illustrates a process of multiplication of the mechanism of discipline in order to detect every potential non-producer of value there. It is thus an economy of power. But how can we understand the economic character of disciplinary power?

Marx understands capitalism as a mode of production that appears to be necessary, despite its contingent and transitory character. Foucault, on the other hand, argues that for money to become capital, it is necessary to keep human existence to its singular features (traits singuliers). This statement points out that the economy of power, which is present in the modern rule of law, develops a disciplinary writing which analyses the individual "[...] in his particular evolution, in his own aptitudes or abilities, under the gaze of a permanent corpus of knowledge; and, secondly, the constitution of a comparative system that made possible the measurement of overall phenomena" (Foucault 1995, 190). It is not then a question of knowing what human beings are: it is a matter of reducing them to data in motion that react uniformly to certain changes in their environment. Foucault $(1995,220-21)$ calls this process the accumulation of human beings (accumulation des hommes). This process is correlative to the accumulation of capital, since it is impossible to force an individual to work if he or she has not become a piece of data in motion, if he or she has not understood the danger of political crime, if he or she has not inhabited a disciplinary common world.

Mystified alienation appears in Foucault's argument because there are, in modern societies, disciplinary powers that exercise over bodies a coercion which, although weak, makes human bodies stronger for obedience, but weaker for disobedience. In Foucault's own words: "If economic exploitation separates the force and the product of labour, let us say that disciplinary coercion establishes in the body the constricting link between an increased aptitude and an increased domination" $(1995,138)$.

Following a different path, Silvia Federici, in Caliban and the Witch (2014), points out that capitalism mystifies human relations by confining women's bodies to the space of meaninglessness. Accordingly, I will point out that patriarchal violence, like disciplinary power, seeks to make invisible political practice and the non-alienated way of life.

\section{Federici: Patriarchy as Alienating Violence}

In Caliban and the Witch (2014), Silvia Federici expresses her just discontent with Marx and Foucault. In her opinion, these two authors, although they make a splendid critique of the conditions that establish capitalism, neglect the fundamental violence that allowed the development of the conditions of the capitalist mode of production: that of patriarchy. Foucault in his analysis of disciplinary power argues that alienating practices take place on bodies in an undifferentiated sense, without taking into account the disciplining of women. In Federici's own words:

Foucault's analysis of the power techniques and disciplines to which the body has been subjected has ignored the process of reproduction, has collapsed female and male histories into an undifferentiated whole, and has been so disinterested in the "disciplining" of women that it never mentions one of the most monstruous attacks on the body perpetrated in the modern era: the witch-hunt $(2014,8)$.

Following this critique of the critique of capitalism, Federici also highlights this same omission in Marx's work. Although Marx initiates a tradition of the critique of capitalism that analyses the period of the emergence of the original accumulation of capital in the Western world, he does not mention "the profound transformations that capitalism 
introduced in the reproduction of labour-power and the social position of women" $(2014,63)$. Marx, like Foucault, also left aside the great witch hunts in the 16th and 17th centuries, even though this violence was paramount in the annihilation of the common use of land and the accumulation of human beings of disciplinary power. For this reason, if we do not consider the patriarchal feature of capitalism, the critique of mystified alienation is incomplete. Following Federici's point of view, the reason for the importance of approaching the critique of alienation from a feminist perspective is obvious: since the transition from feudalism to capitalism, and even in the new forms of reinvention of capitalist exploitation, women have suffered a process of social degradation that has been central to the accumulation of capital and the accumulation of bodies (Federici 2018a, 131). ${ }^{5}$ In accordance with this indication, I propose to argue that Federici's political theory allows the settling of the debt of Marxism with feminism, following the impeccable critique of alienation that emerges from the feminist position.

The disciplining of women, following Federici, can be understood from the following paradox of capitalist alienation. On the one hand, the primitive accumulation of capital or accumulation by dispossession implies an exercise of extreme violence, even in the necropolitical ${ }^{6}$ order, which has as its correlate population decrease and famine. However, on the other hand, as Foucault himself appreciates, capitalist production increasingly requires converted value-producing lives, that is, lives reduced to their singular and simple features. On this horizon, Federici's critique places the degradation of women at the very heart of capitalist reproduction. Population decline and the scarcity of land and food pose the need to pay special attention to women, because the fundamental process of production and reproduction of capitalism falls on them: the production of life or, for capital, the reproduction of labour power. This contradiction between extreme forms of violence that produce death and the need to ensure a production of lives allows Federici to point out that capitalist alienation cannot be addressed without its patriarchal trait, without the violence of the State and that of men over women's bodies. With this in mind, I propose to put patriarchal violence in dialogue with Marx fand Foucault, following the concept of mystified alienation.

I have said that for Marx, alienation supposes the development of objective and subjective conditions for the valorisation of capital, promoting a fraudulent exchange between the worker and the capitalist. I have also indicated that disciplinary power is a form of mystification because it establishes a disembodied reality that prepares human existence to make its submission and its usefulness equivalent for the valorisation of capital. Taking this horizon into account, I would like to add the crucial contribution of Federici. The degradation of women in capitalist production is part of this process of capitalist alienation because it implies, in an incontrovertible way, a fraudulent transaction between men and women. Federici's hypothesis consists in showing that capital, by alienating the daily life of workers, alienates women's bodies at the same time and to a greater degree of submission. For this reason, in Federici's opinion, the disciplining of women's bodies occurs with greater intensity than that of men, because if the former count as bodies that valorise capital, women valorise capital without

${ }^{5}$ As Rita Segato (2016) points out, patriarchal violence pre-dates capitalism. However, in the transition from feudalism to capitalism, not only did an exclusion of women from public affairs take place, but also an ontological degradation. Reproduction and domestic work ceased to count as an important task in the common world. Women's control over their own bodies also started to be criminalised.

'I would like to highlight Esposito's (2008) and Mbembe's (2011) positions on how the forms of domination of capitalism have their necropolitical side. I develop this horizon in Fajardo (2019). 
counting as producers of value. Here the work of care and the reproduction of life come into play. The objective conditions of mystified alienation thus force women's bodies to work without their being recognised as workers. They contribute with life and care to the world of capital valorisation, but their condition excludes them from recognition as value-producing bodies. Now, what does this non-recognition and this higher degree of alienation entail?

According to Federici, women have historically been closer to the common use of land. The common fields, which began to disappear in the sixteenth century (Federici 2018a, 114-21), were fundamental for weaving bonds of solidarity and peasant forms of mutual support. However, the position of women in these common lands had a certain specificity.

The social function of the commons was especially important for women, who, having less title to land and less social power, were more dependent on them for their subsistence, autonomy, and sociality [...] the commons too were for women the center of social life, the place where they convened, exchanged news, took advice, and where women's view point on communal events, autonomous from that of men, could form (Federici 2014, 71-72).

This movement of bodies coming together to weave relationships represented a threat to both the nascent capitalist accumulation and the accumulation of human beings. Hence, the massive processes of land expropriation documented by Marx in Chapter XXVI of Capital (2004a, 704-50) had a greater impact on women's bodies, as they were dispossessed of their social life, of their autonomy and of their common world that allowed them to understand themselves as persons with the capacity for political agency. However, Federici gives us a second clue: in that common life, women had a certain freedom to make decisions about births. They had various means of interrupting their pregnancies, as well as trusted female midwives who allowed them to lead a reproductive life subject to their possibility of deciding when the conditions offered them the opportunity to become mothers. However, population decrease arising from multiple factors, and the need to guarantee human lives willing to value emerging capital, placed women's bodies in the sights of more extreme forms of alienation. Thus began the witch-hunt.

We may observe that human lives and therefore births begin to matter for the State and for men not so much to give them a good life (as their mothers did before the 16th century), but to dispossess them of that good life. Thus, at the same time as the dispossessing of the commons, women's bodies began to be criminalised through extreme forms of disciplining and violence. This allows Federici to argue that the domination of capital over human lives was catastrophic for women, since their capacity to produce life subjected them to forced labour and degraded their condition in the social order to the point of submitting them to the direction of capital to a greater degree of subjugation than that of men. Federici thus radicalises the postulates of the Marxist critique of alienation. In closing this section, I would like to develop how the feminist position problematises and at the same time complements Marxism, providing this tradition with more analytical tools to explore the political practice of human beings.

As I stated earlier, for Marx, mystified alienation is fundamental to understanding that both the capitalist and the worker are governed by conditions that are not external to them. ${ }^{7}$ With Foucault I showed that disciplinary power is a form of mystification, for through its devices human lives become singular and simple, bare lives. However, the

\footnotetext{
${ }^{7}$ Federici's critique of Marxism is also to be found in Federici (2018b).
} 
hope of Foucault is to remember that our human condition weighs upon us as the curse of being subjects of power, of the historical conditioning that, in addition to making possible the submission of bodies, also makes possible resistance and political practice.

Now I come to the point at which feminism radicalises both Marx's and Foucault's critique. Federici $(2014,133-62)$ recalls that the representatives of the human condition in its resistant form are women: not because there is more insubordination and rebelliousness in their DNA than in that of masculinised bodies, but because the capitalist mode of production needs to subdue women's bodies to a greater degree than men's bodies. The extreme violence of capital on human bodies begins when life in common is pathologised and criminalised. Federici gives this form of common life (which is a way of experiencing life in a non-alienated way) the name of "magic", which for witchhunters is the name of evil practices and thoughts. With the noun "magic", Federici seeks to encompass all activity that actualises our condition of being non-alienated beings, beings who realise that the world is inhabited by contingent processes and question again and again the existential disaster that befalls us when we become existences that only contribute, in a potential way, value to capital. These words are significant in that direction:

The battle against magic has always accompanied the development of capitalism, to this very day. Magic is premised on the belief that the world is animated, unpredictable, and that there is a force in all things: "water, trees, substances, words..." (Federici 2014, 80).

\section{Conclusion}

Following Marx's work from 1858 onwards, specifically Capital (2004a), it has been shown that capitalism is a mode of production that appears to be necessary and definitive. To this process I gave the name of alienation in its mystified form. Mystified alienation is not a matter of an illusion or a lie that capitalism produces, but of a complex of impersonal processes that force bodies to make certain choices instead of others. Mystification is thus a historical process which, to preserve itself, seeks to pathologise and criminalise its own limits. As I have shown, these limits are the non-alienated forms of life. The scandal of political practice consists in revealing that the process of valorisation of capital is an ontological disaster because it denies the condition of life in common, that is, a form of life whose principle is experimentation and the search for other forms of experience that go beyond a life reduced to its singular features.

Marx's approach can be updated following two suggestions within contemporary political philosophy. On the one hand, I was interested in highlighting that mystification can be understood from the point of view of disciplinary power. In that direction, Foucault's position contributes to clarify how capitalism institutes a disembodied reality that shapes not only juridical institutions, but also the conditions for bodies to be apt for obedience, that is, bodies reduced to their singular features. The result of this disciplinary power is criminalisation and the pathologisation of political practice in its resistant form. On the other hand, Federici's perspective shows the patriarchal feature of mystified alienation. According to this approach, patriarchal violence subordinates women's lives to a greater degree, because their bodies are closer to a non-alienated form of life. Thus, violence against women is a violence against the limits of capital valorisation. The consequence of this analysis then allows us to understand why women's bodies are reduced to their singular features, making their activities senseless. 
What is then the alternative to this violence of mystified alienation? As I suggest at the beginning of this article, I consider that one of the critical tools of Marxism is to teach us to understand social formations. This process of understanding, in addition to making us see the structural violence that circulates in capitalism, allows us to see, at the same time, its limits: the forms of life that have always resisted the madness of capital valorisation. As Patrick Eiden-Offe (2017) suggests, Marx is a son of an era that produced a poetry of emancipation that describes and speaks of reality and its contradictions.

\section{References}

Abensour, Miguel. 1998. La Democracia Contra El Estado. Marx y El Momento Maquiaveliano. Buenos Aires: Colihue.

Arendt, Hannah. 2018. The Human Condition. Chicago: University of Chicago Press.

Eiden-Offe, Patrick. 2017. Die Poesie Der Klasse. Romantischer Antikapitalismus Und Die Erfindung Des Proletariats. Berlin: Matthes \& Seitz Berlin.

Esposito, Roberto. 2008. Bios: Biopolítica y Filosofía. Buenos Aires: Amorrortu.

Fajardo, Christian. 2020. The Common in the First Volume of Karl Marx's Capital. Izquierdas 49: 3005-23.

Fajardo, Christian. 2019. Política y Biopolítica: Una Aproximación Desde Foucault, Agamben y Rancière. Ciencia Política 14 (28): 197-222. https://doi.org/10.15446/cp.v14n28.76538

Federici, Silvia. 2018a. El Calibán y La Bruja. Buenos Aires: Tinta Limón.

Federici, Silvia. 2018b. El Patriarcado Del Salario. Críticas Feministas Al Marxismo. Madrid: Traficantes de sueños.

Federici, Silvia. 2014. Caliban and the Witch. New York: Autonomedia.

Foucault, Michel. 1995. Discipline and Punish: The Birth of the Prison. New York: Vintage Books. https://search.library.wisc.edu/catalog/999495361202121

Han, Byung-Chul. 2012. La Sociedad Del Cansancio. Barcelona: Herder.

Harvey, David. 2018. Universal Alienation. In Marx @ 200: Debating Capitalism \& Perspectives for the Future of Radical Theory, edited by Christian Fuchs and Lara Monticelli. tripleC: Communication, Capitalism \& Critique 16 (2): 424-439.

Jaeggi, Rahel. 2014. Alienation. Edited by Frederick Neuhouser. New York: Columbia University Press. https://doi.org/10.7312/jaeg15198

Marx, Karl. 2017. El Capital. Madrid: Siglo XXI Editores.

Marx, Karl. 2013. Manuscritos de Filosofía y Economía. Madrid: Alianza Editorial.

Marx, Karl. 2007. Elementos Fundamentales Para La Crítica de La Economía Política (18571858) (Grundrisse). México: Siglo XXI Editores.

Marx, Karl. 2005. The Economic and Philosophic Manuscripts. In Collected Works 3. New York: International Publishers: 229-248.

Marx, Karl. 2004a. Capital. In Collected Works 35. New York: International Publishers.

Marx, Karl. 2004b. Sobre La Cuestión Judía. Buenos Aires: Prometeo.

Marx, Karl. 1987. Gesamtausgabe, 6. Berlin: Dietz Verlag.

Marx, Karl. 1978. The Eighteenth Brumaire of Louis Bonaparte. In Collected Works 11. New York: International Publishers: 99-199.

Marx, Karl. 1975. Contribution to the Critique of Hegel's Philosophy of Law. In Collected Works 3. New York: International Publishers: 3-129.

Marx, Karl. 1973. Grundrisse. London: Penguin Group.

Mbembe, Achille. 2011. Necropolítica. Madrid: Editorial Melusina.

Merleau-Ponty, M. 2010. Oeuvres. Paris: Gallimard.

Negri, Toni and Michael Hardt. 2018. The Multiplicities within Capitalist Rule and the Articulation of Struggles. In Marx @ 200: Debating Capitalism \& Perspectives for the 
Future of Radical Theory, edited by Christian Fuchs and Lara Monticelli. tripleC: Communication, Capitalism \& Critique 16 (2): 440-448.

Rancière, Jacques. 1995. La Mésentente. Politique et Philosophie. Paris: Galilée. Segato, Rita. 2016. La Guerra Contra Las Mujeres. Bogotá: Traficantes de sueños. Žižek, Slavoj. 2008. The Sublime Object of Ideology. London: Verso.

\section{About the Author}

Christian Fajardo

Assistant Professor, Department of Political Science, Universidad Javeriana, Bogotá, Colombia. His research preferences focus on contemporary political philosophy and post-Marxism. 